THE WRITINGS OF ROBERT MOTHERWELL 


\section{THE DOCUMENTS OF TWENTIETH-CENTURY ART}

\section{JACK FLAM, General Editor}

ROBERT MOTHERWELL, Founding Editor

Volumes available from University of California Press:

Art as Art: The Selected Writings of Ad Reinhardt, edited by Barbara Rose

Memoirs of a Dada Drummer by Richard Huelsenbeck, edited by Hans J. Kleinschmidt

Matisse on Art, Revised Edition, edited by Jack Flam

German Expressionism: Documents from the End of the Wilhelmine Empire to the Rise of National Socialism, edited by Rose-Carol Washton Long

Robert Smithson: The Collected Writings, edited by Jack Flam

Flight Out of Time: A Dada Diary by Hugo Ball, edited by John Elderfield

Pop Art: A Critical History, edited by Steven Henry Madoff

The Collected Writings of Robert Motherwell, edited by Stephanie Terenzio

Conversations with Cézanne, edited by Michael Doran

Henry Moore: Writings and Conversations, edited by Alan Wilkinson

Primitivism and Twentieth-Century Art: A Documentary History, edited by Jack Flam with Miriam Deutch

The Cubist Painters, Guillaume Apollinaire, translated, with commentary, by Peter Read 


\section{The Writings of Robert Motherwell}

EDITED BY DORE ASHTON WITH JOAN BANACH

INTRODUCTION BY DORE ASHTON

뚜

UNIVERSITY OF CALIFORNIA PRESS

BERKELEY LOS ANGELES LONDON 
The publisher gratefully acknowledges the generous contribution to this book provided by the Art Endowment Fund of the University of California Foundation, which is supported by a major gift from the Ahmanson Foundation.

University of California Press, one of the most distinguished university presses in the United States, enriches lives around the world by advancing scholarship in the humanities, social sciences, and natural sciences. Its activities are supported by the UC Press Foundation and by philanthropic contributions from individuals and institutions. For more information, visit www.ucpress.edu.

University of California Press

Berkeley and Los Angeles, California

University of California Press, Ltd.

London, England

C 2007 by The Regents of the University of California Robert Motherwell's writings $\odot$ Dedalus Foundation, Inc. All illustrations $\odot$ Dedalus Foundation, Inc., licensed by VAGA, New York.

Library of Congress Cataloging-in-Publication Data

Motherwell, Robert.

The writings of Robert Motherwell / edited by Dore Ashton with Joan Banach.

p. $\mathrm{cm} .-$ (Documents of twentieth-century art) Includes bibliographical references and index.

ISBN 978-0-520-25047-5 (cloth : alk. paper) ISBN 978-0-520-25048-2 (pbk. : alk. paper)

I. Art, Modern-2oth century. I. Ashton, Dore.

II. Banach, Joan. III. Title.

N6490.M75 2007

$709.04-\mathrm{dc22}$

2006039174

Manufactured in the United States of America

$\begin{array}{llllllllll}16 & 15 & 14 & 13 & 12 & \text { II } & \text { IO } & 09 & 08 & 07\end{array}$

$\begin{array}{llllllllll}10 & 9 & 8 & 7 & 6 & 5 & 4 & 3 & 2 & 1\end{array}$

The paper used in this publication meets the minimum requirements of ANSI/NISO Z39.48-1992 (R 1997) (Permanence of Paper). 